\title{
COMPETITION VERSUS COÖPERATION IN THE STEAM- SHIP BUSINESS: PROPOSED LEGISLATION
}

\author{
By Emory R. Johnson, Ph.D., Sc.D., \\ Professor of Transportation and Commerce, University of Pennsylvania; \\ Member of the Public Service Commission of Pennsylvania.
}

Shippers whether by rail or by water routes require, first of all, adequate and regular services at reasonable and relatively stable rates. The primary consideration is that of service. Under present-day conditions, the rates charged, though of importance to shippers, seldom impose serious restrictions upon trade, and it is probable that commercial transactions suffer more from frequent fluctuations in charges than from unreasonably high rates.

Carriers, particularly steamship lines, require, for the successful development of their business, a dependable volume of traffic moving in a steady flow and at rates that yield returns high enough to enable the carriers readily to secure the capital needed to develop adequate and up-to-date terminals and to provide the ships and other facilities required to handle a growing tonnage of traffic. Success in the transportation business doubtless depends more upon a steady volume of traffic than upon a large tonnage if it be fluctuating in volume. The steadier the flow of traffic the more fully can facilities and floating equipment be utilized; the greater the fluctuation in tonnage, the larger the unprofitable movement of vessels partly loaded or in ballast.

The net profits obtained by carriers ought, in the interest of the public as well as in the interest of the owners of railroads and steamships, to be large enough to attract capital to the transportation business; and the conditions under which transportation services are rendered ought to be such as to cause men having capital to invest and having a desire to achieve success in business to wish to devote their money and energies to the construction and operation of railroads and to the building and running of steamships.

The extent to which competition among railroads or among steamship lines should be insisted upon by law and regulation, and the degree of coopperation among rival carriers that should be permitted by the government must, in the last analysis, be decided with 
reference to the effect of competition and coöperation upon the services and rates secured by shippers and upon the present prosperity and future prospects of rail and water carriers. It was formerly thought that the public interests required the fullest possible measure of competition in the transportation business, but experience has shown that the public does not necessarily suffer, and may benefit, from some forms of coöperation among rival carriers. It is the purpose of this paper to inquire to what extent there is coöperation among rival steamship lines and to consider the regulation that should be exercised by the Government.

Competition, it should be remembered, may be in rates or in services, or in both. Rival steamship lines combine or coöperate first of all to agree upon rates, and, secondarily, to regulate their services in such a way as to secure the best use of their facilities. Experience shows that agreements among rival carriers as to rates and services do not put an end to the efforts of the several companies that are parties to the agreement to secure business. Each company is managed by energetic and ambitious men who endeavor to attract passengers and tonnage to the vessels in which they are severally interested. Competition in service continues and the coöperation of steamship lines mitigates but does not terminate the operation of the law of increasing returns. Under normal conditions, every steamship manager strives to secure additional traffic, because more passengers and more tonnage mean less cost and more profits per unit of business handled.

Whatever the theory may be as to competition or coöperation in the steamship business, the fact is that there is at the present time a very large degree of coöperation among carriers by water. This is true both in the foreign trade and in the coastwise commerce of the United States. As Professor S. S. Huebner states in the comprehensive and valuable report which he made in 1914 to the Committee on the Merchant Marine and Fisheries of the House of Representatives (p. 281):

As regards nearly every foreign trade route, practically all the established lines operating to and from American ports work in harmonious coöperation, either through written or oral agreements, conference arrangements, or gentlemen's understandings. The few instances where two or more lines serve the same route and have denied the existence of written or oral agreements for the regulation of the trade, are exceptions and not the rule. 
The coöperation among the carriers engaged in the coastwise trade of the United States is not quite so complete, but Professor Huebner states (ibid., 403) that "with the exception of the Pacific coast trade proper. . . . the line traffic is handled by comparatively few companies and these are largely controlled by railroads and shipping consolidations." Professor Huebner further states (p. 405) that-

On the Great Lakes the through package freight from the western gateways to eastern seaports via Buffalo is controlled exclusively by six railroad-owned boat lines. . . .

Even in the Pacific coast trade (including the intercoastal trade), where independent steamship lines make a more prominent showing than in either the Atlantic coast or Great Lakes trade, railroads and shipping consolidations represent a large proportion of the total tonnage.

In the recommendations which the House Committee on the Merchant Marine and Fisheries adopted at the close of its investigation of "Steamship Agreements and Affiliations in the American Foreign and Domestic Trade," the committee summarizes the present relations of ocean carriers engaged in the American foreign trade in the following concise language (p. 415):

It is the almost universal practice for steamship lines engaging in the American foreign trade to operate, both on the in-bound and out-bound voyages, under the terms of written agreements, conference arrangements or gentlemen's understandings, which have for their principal purpose the regulation of competition through either (1) the fixing or regulation of rates, (2) the apportionment of traffic by allotting the ports of sailing, restricting the number of sailings, or limiting the volume of freight which certain lines may carry, (3) the pooling of earnings from all or a portion of the traffic, or (4) meeting the competition of non-conference lines.

It is recognized by everybody that unfair and destructive competition among carriers is not desirable. When the Interstate Trade Commission bill was before the Senate, the following amendment, introduced by Senator Cummins of Iowa, was adopted by the Senate.

"That unfair competition in commerce is hereby declared unlawful.

"The commission shall have authority to prevent such unfair competition."

The commission, after hearings, may order a person or corporation to desist from unfair practices and- 
Any suit brought by any such person, partoership, or corporation to annul, suspend, or set aside, in whole or in part, any such order of the commission shall be brought against the commission in a District Court of the United States in the judicial district of the residence of the person or of the district in which the principal office or place of business is located, and the procedure set forth in the act of Congress making appropriations to supply urgent deficiencies and insufficient appropriations for the fiscal year 1913, and for other purposes relating to suits brought to suspend or set aside, in whole or in part, an order of the Interstate Commerce Commission shall apply.

This legislation indicates that the public has come to realize that some restriction should be placed upon competition that is unfair and destructive, and experience will probably show that carriers in order to keep competition within fair limits, must be allowed some measure of coöperation.

In deciding upon the degree or form of coöperation that should be allowed rival steamship companies, the advantages claimed for coöperation should be considered, and the objections to interline agreements should be kept in view. It will be well to summarize, briefly, the advantages and disadvantages resulting from the coöperation of steamship companies with each other. These advantages and disadvantages are set forth in Professor Huebner's report, above referred to (pp. 300-307).

It is contended by the carriers, and it was the opinion of Professor Huebner and the House Committee on the Merchant Marine and Fisheries, that agreements among ocean carriers as to rates and services are a "protection to both shipper and ship owner." It was represented to the committee that the coöperation of rival steamship lines gave shippers a more regular service, that regularity of service enabled merchants to build up their trade, to reach a greater number of markets, and to carry smaller stocks of goods with consequent lower storage charges. A regular, dependable service, furthermore, enables merchants to avoid engaging cargo space in advance and yet to count upon being able to deliver goods at definite future dates. By means of agreements, it was pointed out to the committee, merchants trading in the United States may have a service comparing in regularity with the service from European countries, which together have a much larger foreign trade than is handled to and from the United States. Agreements, likewise, give a better distribution of sailings by dates and ports and permit exports to be shipped from 
the interior of the United States to foreign countries with the minimum detention at the seaboard.

The other advantages resulting from agreements between steamship lines, stated briefly, are the greater security given to capital invested in the steamship business, more stable, uniform and equitable rates of insurance payable by merchants, the stability of freight and passenger charges, the securing of uniform freight rates by all merchants, large and small, the maintenance of rates from the United States to foreign markets that are equal to, or fairly related to, those from other countries, the reduction in the cost of service to the carrier, and the distribution of the total cost of all the services of the lines, parties to the agreement, over the traffic as a whole in such a way as to make possible the largest development of the total trade.

Obviously, it is possible that the public may suffer by allowing ocean carriers freely to enter into agreements concerning their services and rates. Disadvantages to the public may result from the monopolisitic nature of the conferences or agreements of carriers. The very purpose of the agreement is to limit competition, and monopoly is the antithesis of competition. If carriers were not restrained by economic forces or statutory law, they would doubtless establish a degree of monopoly that would be injurious to the public. Where competition is restricted by combinations of carriers, it is usually necessary for the Government to protect the public interest by intelligent regulation.

Another objection urged against conference agreements of steamship lines is that the agreements, as now made and enforced, are secret. This practice violates the well-established principle that there should be no secrecy in the business of common carriers; their relations with each other and to the public should be matters of public knowledge.

It is, moreover, the practice of some steamship companies, by permission of the conference agreements, to grant more favorable rates, on certain classes of commodities, to large shippers than are given smaller shippers. This discrimination among shippers tends to give to the more favored shippers a monopoly of trade, to the injury of the public as a whole. For the most part, it is the policy of steamship companies to grant the same rates to large and small shippers, and this is the only wise policy.

Furthermore, in the long-distance trade between the United 
States and South America, Africa, Asia and Australasia, the wellknown system of deferred rebates to loyal shippers prevails to a large extent in the traffic to the United States. The practice of making a rebate of 5 or 10 per cent in the freight charges, payable six months or a year subsequent to the termination of the period in which the shipments were made, but payable only to such shippers as have patronized the conference lines exclusively, ties shippers to the conference lines so closely as to prevent independent lines from entering into competition with the lines parties to the conference. The carriers consider deferred rebates necessary in certain trades. Whether they are in the interest of the public or whether they are necessary to the carriers is debatable; probably, they should be prohibited.

Certain practices of conference lines are subject to criticism and seem to show the necessity for regulation of the conference agreements and the services and practices of ocean carriers. Some of these practices will be considered in reviewing the recommendations made by the Committee on the Merchant Marine and Fisheries concerning the regulations of carriers by water. The practices considered undesirable by the committee are dealt with in the bill which the committee has introduced and which is now pending in Congress. (See appendix IV to this volume).

The views of the House Committee on the Merchant Marine and Fisheries as to the advantages of coöperation among carriers by water are entitled to great weight, and may well be quoted in this connection (p. 416):

It is claimed that . . . the prohibition of coöperative arrangements between practically all the lines in nearly all the divisions of our foreign trade would not only involve a wholesale disturbance of existing conditions in the shipping business, but would deprive American exporters and importers of the advantages claimed as resulting from agreements and conferences if honestly and fairly conducted, such as greater regularity and frequency of service, stability and uniformity of rates, economy in the cost of service, better distribution of sailings, maintenance of American and European rates to foreign markets on a parity, and equal treatment of shippers through the elimination of secret arrangements, and underhanded methods of discrimination.

These advantages, the committee believes, can be secured only by permitting the several lines in any given trade to coöperate through some form of rate and pooling arrangement under Government supervision and control. It is the view of the committee that open competition can not be assured for any 
length of time by ordering existing agreements terminated. The entire history of steamship agreements shows that in ocean commerce there is no happy medium between war and peace when several lines engage in the same trade.

It seems clear that coöperation among steamship lines is desirable but that it would not be wise to give rival carriers whether on land or sea unrestricted freedom in combining to restrain competition. It is necessary for the Government to lay down the conditions under which carriers may coöperate and for the Government so to regulate the agreements of carriers with each other and with shippers and passengers as to secure, if possible, for both the carriers and the public, the advantages obtainable from the coöperation of carriers without thereby allowing the public to be oppressed by arbitrary or monopolistic action on the part of the carriers. In legislating for the regulation of ocean carriers, the fact should be kept in mind that the chief aim of the Government as well as of the carriers should be to provide shippers with services of maximum quality and quantity. No academic theories as to government restriction of monopoly and enforcement of competition, nor any general theory as to government regulation of rates and services of common carriers should interfere with the maintenance and development of transportation services.

The best thought concerning the extent to which the Government should regulate the agreements of rival ocean carriers is that presented in the recent report of the House Committee on the Merchant Marine and Fisheries. As the result of its careful investigation, the committee concluded that the agreements were desirable from the point of view of the public interest as well as from the viewpoint of the welfare of the carriers, but it also believed that it is necessary to have "some form of effective government supervision." It was the belief of the committee that "the advantages and abuses connected with steamship agreements and conferences as now conducted are inherent and can be eliminated by only effective government control," and the committee recommended the following measures for the regulation of steamship carriers engaged in the foreign trade of the United States:

1. That firms or lines engaged in the foreign trade be subject to the supervision of the Interstate Commerce Commission as regards rates and the approval of contracts with each other, with shippers and with railroads. 
2. That carriers engaged in the foreign trade be required to file with the Interstate Commerce Commission, for approval, agreements with other steamship companies, or with shippers or with railroads.

3. That the Interstate Commerce Commission be given ample powers to make investigation upon complaint or upon its own motion, the commission to have power to correct unjust rates, to supervise classifications of freight and to adjust rates among classes of commodities.

4. That the granting of rebates be made illegal and that carriers be required to charge equal rates to shippers irrespective of volume of freight offered.

5. That the Interstate Commerce Commission be given the power to make investigations, upon complaint or upon its own motion, to determine whether carriers have given reasonable notices of increased rates; whether shippers have been unfairly treated as regards cargo space and other facilities; whether the carriers have made discriminating or otherwise unfair contracts with favored shippers; and to determine whether the carriers have equitably settled claims against them.

6. That carriers be prohibited from employing "fighting ships" to drive out of business companies not members of a conference. Fighting ships, it may be necessary to explain, are vessels temporarily put into service to carry freight at exceptionally low rates to and from ports served by lines outside of the conference, the losses incurred in the operating of fighting ships being borne by the lines belonging to the conference.

7. The committee further recommends the prohibition of the payment of deferred rebates to loyal shippers, both in the import and export trade of the United States.

Certain special additional recommendations, applicable to carriers by water engaged in the domestic trade, were made by the committee. The more important of these recommendations are the following: That the Interstate Commerce Commission be given complete jurisdiction over interstate port-to-port traffic of coastwise carriers, with power to fix maximum rates; that railroads be prohibited from making a through rail-and-water route prohibitive as compared to an all-rail route by charging "more for the same service on water-borne commodities than they charge for the proportionate share of the rail haul;" that the Interstate Commerce Commission 
be given power to allow carriers by water to charge differentials enough lower than competing rail rates to enable the carriers by water to secure a fair share of the traffic; that railroads and carriers by water be required to issue through bills of lading over lines of interstate carriers by water; that railroads be required to allow carriers by water to use the railroad terminal facilities under like, fair conditions; and that the railroads be prohibited, in the future, from securing control of canals or companies engaged in transportation by canals.

Since the Committee on the Merchant Marine and Fisheries completed its report and formulated the above recommendations, Hon. J. W. Alexander, Chairman of the Committee, with the assistance of Professor S. S. Huebner, has drafted a bill for the regulation of carriers by water, which bill is now pending in Congress. A copy of the proposed legislation is printed as an appendix IV to this volume. Inasmuch as the primary purpose of the bill is to regulate the agreements and the practices of steamship conferences which are formed to regulate competition in the business of transportation by water, it will be appropriate to devote the remainder of this paper to a consideration of the principal features of the bill that has been presented to Congress.

After defining, in the first section of the bill, the term "common carrier by water" and drawing the necessary distinction between such carriers "in interstate commerce" and "in foreign commerce," the bill, in section two, prohibits the granting of deferred rebates, the operation of fighting ships, and retaliatory action by carriers against shippers for patronizing non-conference lines. These provisions reach the chief abuses of the steamship conferences. Unquestionably, fighting ships ought to be prohibited; by their use unfair competition is waged against independent carriers. The use of fighting ships to destroy competitors is analagous to the practice of local price cutting by trusts to drive small competitors out of business. It is also desirable to prohibit the granting of deferred rebates to loyal shippers, although it must be recognized that such rebates may not be without advantage to shippers as well as to carriers. It is believed, however, that the advantages of deferred rebates are more than offset by the fact that such rebates secure to the carriers, that are members of a conference, a monopoly that may be dangerous to the public interest. Probably, deferred rebate agreements are 
a violation of the anti-trust law and could not be lawfully entered into by carriers subject to that act.

Section three of the bill provides that conference agreements must be filed with the Interstate Commerce Commission, which is given power to modify or disapprove them. It is necessary that the commission, acting for the Government, should be informed of all agreements and arrangements entered into by steamship lines, members of conferences; although, in a sense, the bill, by giving the Interstate Commerce Commission the power to disapprove or modify these agreements, makes the Government a party to the arrangements entered into by competing carriers. As drafted, the bill apparently assumes that the agreements among carriers may become binding upon the parties to the contracts, as soon as they are executed, although the bill stipulates that "such agreements, understandings, conferences and arrangements shall be approved or disapproved by the Interstate Commerce Commission."

If it is intended that the Interstate Commerce Commission shall formally approve or disapprove the conference agreements, such agreements ought not to become effective until the commission has had reasonable time to consider them and pass upon them. In would seem that the law ought to require the agreement to be filed with the commission at least thirty days before becoming effective. It probably would not be wise to give the Interstate Commerce Commission power to suspend the effective date of such agreements in the manner that it can suspend proposed increases in railroad rates. It will doubtless be best to allow the agreements to become effective without action by the commission thirty days after filing, the commission having power at any time, after hearing initiated upon complaint or upon its own motion, to order the modification or termination of any agreements.

By section four of the bill as drafted,

Every traffic or rate association or conference of which any common carrier by water in interstate commerce may be a member . . . is placed under the jurisdiction of the Interstate Commerce Commission as regards the approval of all matters pertaining to rates, traffic arrangements between carriers, and other conditions of water transportation.

This action, taken with other portions of the act, confers upon the commission clearly the power to approve or disapprove of the rates 
named in conference agreements entered into by carriers by water in interstate commerce. Indeed, by section seven, the commission is given power "to determine, prescribe and order enforced just and reasonable rates" of carriers by water in interstate commerce.

One of the abuses of steamship conferences has been the refusal of the members of an existing conference to admit new members to the association. To meet this situation, section four of the proposed act makes it unlawful for a conference to deny membership "to any carrier because the consent of all or any number of the existing members of such association or conference can not be obtained to favor the admission of said carrier." The commission is given power to prescribe the conditions under which outside lines may become members of existing conferences.

The provisions of section five of the bill write into the proposed act sections two and three of the interstate commerce act which prohibit special rates and rebates and unreasonable discriminations as between persons, places and kinds of traffic. By these provisions, the proposed act will establish new standards of conduct to be observed by carriers by water. It is recognized by those who drafted the bill, and will, in time, come to be recognized by everybody, that secret rates, rebates and unfair discrimination when granted by carriers by water are as contrary to public policy as when given by railroad companies. If the proposed bill becomes a law and is wisely administered, it will mark a long step forward in providing equal opportunity to all shippers and producers, large and small, as regards the services of common carriers by lake and sea as well as by rail.

Sections six, seven and eight of the proposed measure give the Interstate Commerce Commission revisory power over the rates charged by carriers by water. Section six applies to carriers in foreign commerce and sections seven and eight to carriers in interstate commerce. The bill, in section seven, requires carriers by water in interstate commerce to file and keep open to public inspection local and joint rates and fares, and provides that no increase may be made in such charges except upon ten days' notice to the commission, which body is given the power, either upon complaint or upon its own motion, to prescribe maximum rates and fares, and to determine what differentials may be established between the charges of competing rail and water carriers in interstate commerce. By these provisions, the Interstate Commerce Commission 
is given, with two exceptions, the power over the rates of interstate carriers by water that it has over the charges of railroads. The two exceptions are, that interstate carriers by water may reduce rates without giving the commission advance notice, and that the commission has no power to suspend the rates filed by interstate carriers by water.

Common carriers by water in foreign commerce are subjected to less complete regulation than are interstate carriers by water. Section six gives the commission authority to prescribe the maximum rates that may be charged by common carriers by water in foreign commerce, but such carriers are not required to print and file their rates, nor is it made necessary for them to give the commission advance notice of an increase in rates. Section six, however, should be read in connection with section thirteen of the proposed act, which provides that the Interstate Commerce Commission may, at its discretion, require any common carrier by water in foreign commerce

to file with it any periodical or special report, or any account, record, rate, or charge, or any memorandum of any facts and transactions appertaining to the carrier's business, concerning any matter about which the commission is authorized or required by this act to inquire or keep itself informed or which it is required to enforce, or to require from any such carrier specific answers to all questions upon which the Commission may need information in carrying out this act.

Section thirteen probably gives the commission power to require the printing and filing of the tariffs of carriers by water in foreign commerce, and it is suggested that it would be better to change the phraseology of section six of the bill so as to confer, by that section, upon the commission whatever powers it is intended that the act shall give the commission as regards the printing and filing of the rates of carriers in foreign commerce.

There can hardly be any doubt that the printing and filing of the rates is a necessary prerequisite to any intelligent and effective regulation of rates by the commission. In my judgment, it is desirable to require common carriers in foreign commerce to give the commission ten days' notice of increases in rates, with the proviso that the commission, in its discretion, may, upon application, permit certain classes of carriers, without giving the commission advanced notice, to quote higher rates than those on file with the commission. 
The possession of such discretion by the commission would probably enable it to prescribe different regulations or requirements for companies and vessels engaged in "line" and "tramp" services.

It is provided by section eight of the bill that-

Whenever a common carrier by water in interstate commerce reduces its rates . . . below a fair and remunerative basis with the intent of driving out or otherwise injuring a competitive carrier by water, it shall not be permitted to increase such rates unless after hearing by the Interstate Commerce Commission it shall be found that such proposed increase rests upon changed conditions other than the elimination of said competition.

The commission is given power to determine whether the rates in question were actually reduced below a remunerative basis with the intent of driving the competitor out of business. This provision which is taken, with modification, from the interstate commerce act will doubtless do much to prevent carriers by water from starting upon a destructive warfare for the purpose of eliminating competition. The effect, however, will probably be to cause practically all carriers to enter into conference agreements. If competitors can not in the future be driven from the field by warfare, they will need to be made harmless. Steamship companies will seek to become friendly neighbors by means of mutual understandings. This is as it should be, provided the understandings and agreements of the friendly neighbors are known to, and regulated by, the Government.

The remaining sections, nine to twenty-two, of the proposed act, with the exception of sections eleven, thirteen, fourteen and twentyone, do not call for special discussion in this paper. Section nine wisely prohibits carriers, subject to the act, from disclosing other than to shipper or consignee-

any information concerning the nature, kind, quantity, destination, consignee, or routing of any property tendered or delivered to such common carrier for interstate transportation, or for transportation between the United States and a foreign country, which information may be used to the detriment or prejudice of such shipper or consignee, or which may improperly disclose his business transactions to a competitor, or which may be used to the detriment or prejudice of any carrier.

Section ten gives the Interstate Commerce Commission power to adopt such rules and regulations as may be necessary to prevent

unfair treatment of shippers in the matter of cargo space accommodations or other facilities, having due regard for the proper loading of the vessel and the 
available tonnage, or unfair or diseriminating contracts with shippers based on the volume of freight offered, or unfair treatment in the loading and landing of freight in proper condition, or unfair treatment in the adjustment and settlement of claims.

Section eleven is intended to reach and prevent the objectionable practice on the part of railroad companies of charging on traffic received by railroad from connecting carriers by water a higher rate for the rail portion of the through, joint service than the railroads charge for a corresponding rail haul on traffic that is handled by an all-rail route from shipper to consignee. To illustrate: the railroads charge on ex-lake grain a rate from the lakes to the seaboard higher than the proportionate share of an all-rail rate from the middle West to the seaboard. Section eleven reads as follows:

That when property may be or is transported by rail and water from point to point in the United States, and not entirely within the limits of a single State, it shall be unlawful for any railroad company or companies to discriminate against such rail-and-water route, as compared with the all-rail route between the same points, by charging more for the same transportation service, having due regard for reasonable extra terminal charges and other expenses involved, on water-borne commodities and articles moving between said points, than they charge on the same kind of commodities and articles for the proportionate share of the all-rail haul. The Interstate Commerce Commission is hereby empowered upon complaint, or on its own initative and after full hearing, to determine questions of facts as to the violation of the provisions of this section by any railroad company, and to order any such violation discontinued.

Section twelve prohibits railroads and other common carriers from acquiring control of any canal, or any common carrier operating as a canal, when the waterway is used in interstate commerce, unless the acquisition of such control is permitted by the Interstate Commerce Commission "as being in the public interest and of advantage to the convenience and commerce of the people." This will give the Interstate Commerce Commission the power to determine the extent to which it is necessary or desirable to permit the common ownership and operation of railroads and inland waterways.

As was pointed out above, section thirteen gives the Interstate Commerce Commission the power, at its discretion, to require common carriers by water in foreign commerce to make reports and to file rates. It is wise to give the Interstate Commerce Commission 
this discretionary power. Experience with the administration of the act will indicate to the commission how far it will be practicable and wise to go in requiring reports of carriers by water in the foreign trade. In my judgment, it will be found practicable, eventually, to make nearly the same requirements of carriers in the foreign trade as are made of carriers in the coastwise trade, and it is wise to give the commission discretionary power in prescribing rules to be followed by carriers employed in international trade.

It is equally wise, as is provided by section fourteen of the bill, to apply section twenty of the interstate commerce act of 1887 , as amended to date, to "common carriers by water in interstate commerce, as far as the same may be applicable to said carriers." This will enable the Interstate Commerce Commission to require comprehensive annual reports, to prescribe a uniform system of accounts, and to employ agents who shall have authority to examine all accounts and records kept by the carriers by water in interstate commerce.

Sections fifteen, sixteen, seventeen, eighteen and nineteen provide appropriate penalties for violation of the act, and prescribe the procedure for enforcement of the law. While of great importance, these sections do not require discussion in this paper, which has to do with the economic provisions of the proposed law. Section twenty authorizes the commission "to employ such experts and other assistants as may be necessary, and to appoint special agents or examiners who shall have powers to administer oaths, examine witnesses and take testimony." Section twenty-two merely provides that the act shall take effect upon its passage.

The enforcement of the act is placed, by section twenty-one, with the Interstate Commerce Commission, which is to be enlarged from seven to eleven members, not more than six of whom shall be adherents of the same political party. This provision of the bill is sure to meet with at last two general criticisms, - - that the Interstate Commerce Commission is now overburdened and unable to keep abreast of its work, and that it will be predisposed to apply to carriers by water the same kind and degree of regulation that it has applied to railroads, and thus subject the business of transportation by water to rules that will be too detailed and too rigid. Those who urge these criticisms will argue for the establishment of a new, autonomous commission charged solely with the duty of regulating carriers by water. 
It is true that the Interstate Commerce Commission is at present over-worked, but the addition of four new members ought to enable the commission not only to perform its new duties satisfactorily, but also to expedite its work of regulating railroads. The combined task of regulating the rail and water carriers can doubtless be performed by eleven men more easily than seven men can handle tbe present work of the Interstate Commerce Ccmmission.

The fear that the Interstate Commerce Commission will go further and faster than would a separate commission with the regulation of carriers by water is probably not well founded. The long experience which the Interstate Commerce Commission has bad in the regulation of railroads, and to some extent in supervising carriers by water, may, indeed, make it more cautious than an entirely new administrative body would be. The Interstate Commerce Commission would certainly approach the task of regulating carriers by water more intelligently than would a new commission, and it would probably make fewer mistakes.

A strong argument against the establishment of a separate commission for the regulation of carriers by water is that if there were two commissions, there might be conflict of jurisdiction, lack of uniformity in regulation and in decisions that would both lessen the effectiveness of regulation and be of disadvantage to shippers and carriers. It will be better to increase the membership of the Interstate Commerce Commission, to provide it generously with facilities for doing its enlarged work, and to entrust it with the task of regulating carriers by water as well as by land. 